\section{Selective Alkylation of Ambient 5-Halopyrimidin-2-one Anion}

\section{MICHEL GACEK and KJELL UNDHEIM}

Department of Chemistry, University of Oslo, Oslo 3, Norway

In our previous report we have described regioselective $N$-alkylations in 5-fluorouracil via methylthio derivatives. ${ }^{1}$ Our interest in the metaphase arresting properties of $\mathrm{N}$-alkyl-5-halopyrimidin-2-one has led us to alkylation studies of 5-chloropyrimidin-2-one 1 as a representative for the 5-halo derivatives in general. ${ }^{2,3}$ In the ambient anion of 1 the nitrogen atoms are equivalent and hence the selectivity problem is restricted to $N$ - or $O$-alkylation. ${ }^{4}$ Phase-transfer catalysis is sometimes 'an effective promoter of $\mathrm{N}$ - over $\mathrm{O}$-alkylation. ${ }^{5,6}$ Therefore the phase-transfer method (A) has been compared with direct alkylation methods using the potassium salt of 1 in DMF (B) or 1 in the presence of triethylamine in methylene chloride (C).

In the alkylation of 1 , phase-transfer catalysis by triethylbenzylammonium chloride (TEBA) in aqueous sodium hydroxide and methylene chloride, however, was not satisfactory except for formation of the benzyl derivative; the butyl derivative was formed in a low yield while the reactions with propargyl and allyl bromides gave polymeric materials. The pyrimidin-2-one is sparingly soluble in methylene chloride, but was readily dissolved in the presence of triethylamine for alkylations. Except for the formation of the $N$-butyl derivative, the alkylation proceeded as well as for the potassium salt of 1 in DMF (Scheme 1). Under the conditions chosen, the alkylation was almost exclusively on

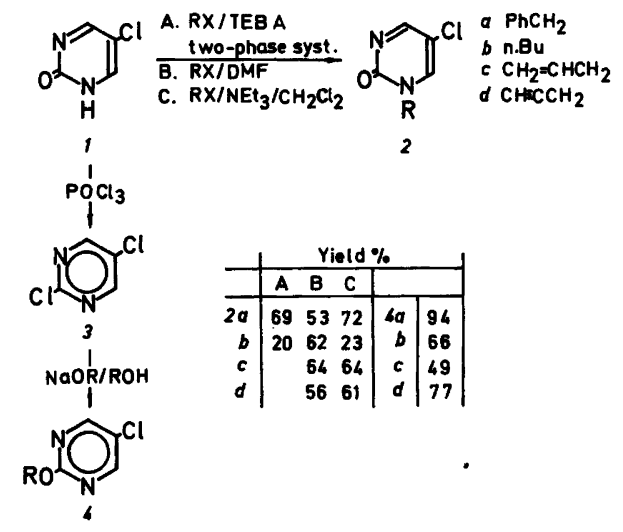

Scheme 1. the nitrogen atom and this appears to be independent of the size of the counterion $\left(\mathrm{K}^{+}, \mathrm{NEt}_{3} \mathrm{H}^{+}\right.$, TEBA) of the pyrimidine anion. Direct alkylation of a pyrimidin-2-one, however, frequently yields a high proportion of $O$-alkylated isomer which may be further increased by using the silver salt of the pyrimidine. ${ }^{4}$ Selective $O$-alkylation has been claimed for simple alkyl groups using the corresponding Meerwein reagent (trialkyloxonium tetrafluoroborate). ${ }^{7}$ In this work the $\boldsymbol{O}$-alkyl isomers needed for structure verifications were prepared via the 2,5dichloride 3 by selective nucleophilic displacement of the 2-chloro substituent by the respective sodium alkoxide (Scheme 1).

By the inclusion of Fig. 1 we want to point out that reverse-phase HPLC has been found to be a simple method for isomer analysis in this field; the $N$-alkyl isomer is eluted before the less polar $O$-alkyl isomer. For preparative separations, straight-phase HPLC on silica gel was used in which case the order of elution of the isomers was reversed.

In ${ }^{1} \mathrm{H}$ NMR the $O-\mathrm{CH}_{2}$ group appears at lower field $(15-25 \mathrm{cps})$ than the $N-\mathrm{CH}_{2}$ group; in the symmetrical $O$-isomer the signals from $\mathrm{H}-4$ and $\mathrm{H}-6$ coincide. The mass spectra formed by chemical ionization using isobutane, are characterized by the strong $[M+H]$ ion; the isomer pairs show similar fragmentations except for the butyl derivatives where the $O$-isomer undergoes a McLafferty type rearrangement with expulsion of the sidechain. Important is also loss of a proton except from the benzyl isomers, which show preferential expulsion of the benzyl group. The electron impact spectra also appear to lack characteristic fragmentations for ready differentiation between the isomers.

Experimental. Paper chromatography was run on Whatman 1 papers using $\mathrm{BuOH}-\mathrm{EtOH}-$

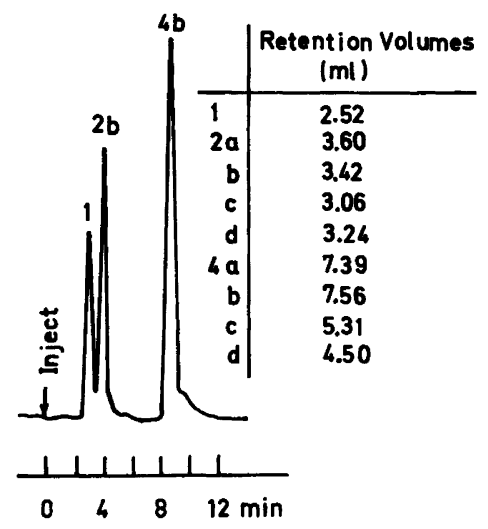

Fig. 1. HPLC on $\mu$ Bondapak $\mathrm{C}_{18}$ column using $63 \% \mathrm{MeCN}$ aq. $(0.9 \mathrm{ml} / \mathrm{min})$. 
$\mathrm{NH}_{3}-\mathrm{H}_{2} \mathrm{O}$ (4:1:2:1). TLC was run on Merck Silica gel $60 \mathrm{~F}_{254}$ using (a) EtOAc, (b) $\mathrm{CHCl}_{3}-$ $\mathrm{Et}_{2} \mathrm{O}$-Acetone (4:1:1), (c) (iPr) ${ }_{2} \mathrm{O}$, or on neutral alumina $60 \mathrm{~F}_{254}$ using $\mathrm{CHCl}_{3}$. $\mathrm{HPLC}$ was run on a Waters HPLC system equipped with a UV monitor fixed at $260 \mathrm{~nm}$ and a $\mu$ Bondapak $\mathrm{C}_{18}$ column (10 $\mu \mathrm{m}, 30 \mathrm{~cm} \times 4 \mathrm{~mm}$ I.D.). The solvent was $63 \%$ aq. acetonitrile, and the flow rate was $0.9 \mathrm{ml} / \mathrm{min}$; the $\mathrm{N}$-isomer is first eluted. For preparative HPLC separation of an isomer mixture the latter $(2 \mathrm{~g})$ was dissolved in DMF $(4 \mathrm{ml})$ and the solution injected onto a Waters PrepPak-500 silica column which was eluted $(100 \mathrm{ml} / \mathrm{min})$ with $30 \%$ hexane in EtOAc; the $O$-isomer is first eluted.

The mass spectra were recorded on MM 70-70F VG Micromass spectrometer. Isobutane was the reagent gas in the chemical ionization mode.

Alkylation of 1. Method A. A solution of the alkyl bromide $(10 \mathrm{mmol})$ and TEBA $(10 \mathrm{mmol})$ in dichloromethane $(40 \mathrm{ml})$ and a solution from 5chloropyrimidin-2-one $(10 \mathrm{mmol})$ in $1 \mathrm{M} \mathrm{NaOH}$ $(15 \mathrm{ml})$ were stirred vigorously together for $18 \mathrm{~h}$ at room temperature. The organic phase was then collected, the aqueous phase extracted with dichloromethane $(3 \times 20 \mathrm{ml})$, the combined dichloromethane solutions washed with a little water and the dried $\left(\mathrm{MgSO}_{4}\right)$ solution evaporated. The residue was dissolved in chloroform $(100 \mathrm{ml})$ and the chloroform solution filtered through alumina $(20 \mathrm{~g}$, "Woelm" neutral, activity III); evaporation of the eluate left the alkylated product. The physical data are given below:

Method $B$. The alkyl bromide $(10 \mathrm{mmol})$ and the potassium salt of 5-chloropyrimidin-2-one ${ }^{8}$ (7 mmol) were stirred together in anhydrous DMF (40 $\mathrm{ml}$ ) at room temperature until the $\mathrm{pH}$ (moistened $\mathrm{pH}$ paper) was neutral. The solvent was distilled off at $1 \mathrm{mmHg}$, the residue extracted with chloroform $(100 \mathrm{ml})$ and the solution filtered through alumina and worked up as above.

Method C: 5-Chloropyrimidin-2-one $(3 \mathrm{mmol})$ was added to a solution of triethylamine $(3 \mathrm{mmol})$ in dichloromethane $(15 \mathrm{ml})$. When a clear solution was obtained the alkyl bromide $(3.3 \mathrm{mmol})$ was added, and the progress of the reaction was monitored by TLC. The reaction mixture was worked up as above.

1-Benzyl-5-chloropyrimidin-2-one 2a: M.p. $197^{\circ} \mathrm{C}$ (EtOAc). Anal. $\mathrm{C}_{11} \mathrm{H}_{9} \mathrm{ClN}_{2} \mathrm{O}: \mathrm{C}, \mathrm{H} .{ }^{1} \mathrm{H}$ NMR $\left(\mathrm{CDCl}_{3}\right): \delta 5.05\left(\mathrm{CH}_{2}\right), 7.33(\mathrm{Ph}), 7.60(\mathrm{H}-4), 8.46$ (H-6). IR (KBr): $1665 \mathrm{~cm}^{-1}$ (CO). MS [70 eV; $m / z$ (\% rel.int.)]: 222/220 (8/26, M), 116(3), 114(5), 91(100); [isoBu]: 223/221 (25/100, M+H), 57(31).

1-Butyl-5-chloropyrimidin-2-one $2 \mathrm{~b}$ : M.p. $125^{\circ} \mathrm{C}$ (benzene). Anal. $\mathrm{C}_{8} \mathrm{H}_{11} \mathrm{ClN}_{2} \mathrm{O}: \mathrm{C}, \mathrm{H}$. ${ }^{1} \mathrm{H}$ NMR $\left(\mathrm{CDCl}_{3}\right): \delta 1.02(\mathrm{Me}), 1.2-2.0\left(\mathrm{CH}_{2} \mathrm{CH}_{2}\right), 3.90$ $\left(\mathrm{N}-\mathrm{CH}_{2}\right), 7.73(\mathrm{H}-4), 8.48(\mathrm{H}-6)$. IR (KBr): $1660 \mathrm{~cm}^{-1}$ (CO). MS [70 eV; $m / z(\%$ rel.int.)]: 188/186 (13/41,
M), $187 / 185 \quad(13 / 31), 146 / 144 \quad(33 / 100), 133 / 131$ (20/62), 118/116 (20/65); [isoBu]: $189 / 187(28 / 100$, $\mathrm{M}+\mathrm{H}), 186(5), 57(9)$.

1-Allyl-5-chloropyrimidin-2-one 2c: M.p. 130$131{ }^{\circ} \mathrm{C}$ (acetone). Anal. $\mathrm{C}_{7} \mathrm{H}_{7} \mathrm{ClN}_{2} \mathrm{O}: \mathrm{C}, \mathrm{H} .{ }^{1} \mathrm{H}$ NMR $\left(\mathrm{CDCl}_{3}\right): \delta 4.51\left(\mathrm{CH}_{2}\right), 5.1-5.4\left(=\mathrm{CH}_{2}\right)$, 5.6-6.3 (CH =), $7.75(\mathrm{H}-4), 8.46(\mathrm{H}-6)$. IR $(\mathrm{KBr})$ : $1670 \mathrm{~cm}^{-1}$. MS [70 eV; $m / z$ (\% rel.int.)]: $172 / 170$ (20/64, M), 171/169(36/100), 118(3), 116(16), 114(29); [isoBu]: 173/171 (30/100, M+H), 170(6), 57(33).

1-Propargyl-5-chloropyrimidin-2-one 2d: M.p. $130{ }^{\circ} \mathrm{C}$ (EtOAc). Anal. $\mathrm{C}_{7} \mathrm{H}_{5} \mathrm{ClN}_{2} \mathrm{O}: \mathrm{C}, \mathrm{H}$. ${ }^{1} \mathrm{H}$ NMR $\left(\mathrm{CDCl}_{3}\right): \delta 2.71(\equiv \mathrm{CH}), 4.70\left(\mathrm{CH}_{2}\right), 8.13$ (H-4), 8.50 (H-6). IR (KBr): $1680 \mathrm{~cm}^{-1}$ (CO). MS [70 eV; $m / z(\%$ rel.int.)]: 170/168 $(21 / 66, \mathrm{M})$, 133(17), 116(7), 114(19), 39(100); [isoBu]: 171/169 $(28 / 100, \mathrm{M}+\mathrm{H}), 168(9), 57(6)$.

2-Alkoxy-5-chloropyrimidine 4. 2,5-Dichloropyrimidine ${ }^{9}(10 \mathrm{mmol})$ was added to $0.8 \mathrm{M}$ sodium alkoxide in the corresponding alcohol $(25 \mathrm{ml})$, and the mixture was stirred at room temperature overnight. The solvent was then distilled off $(1 \mathrm{mmHg})$, the residue extracted with ether $(80 \mathrm{ml})$, the ether solution washed with $2 \mathrm{M} \mathrm{NaOH}(2 \times 10 \mathrm{ml})$ and water. Evaporation of the dried $\left(\mathrm{MgSO}_{4}\right)$ solution left the title product of $4 a, 4 b$ and $4 c$.

2-Benzyloxy-5-chloropyrimidine $4 \mathrm{a}$ : M.p. $98{ }^{\circ} \mathrm{C}$ (light petroleum b.p. $80-100^{\circ} \mathrm{C}$ ). Anal. $\mathrm{C}_{11} \mathrm{H}_{9} \mathrm{ClN}_{2} \mathrm{O}: \mathrm{C}, \mathrm{H}$. ${ }^{1} \mathrm{H}$ NMR $\left(\mathrm{CDCl}_{3}\right): \delta 5.35$ $\left(\mathrm{CH}_{2}\right), 7.28(\mathrm{Ph}), 8.35(2 \mathrm{H}-4.6)$. MS [70 eV; $\mathrm{m} / \mathrm{z}(\%$ rel.int.)]: 222/220(11/34, M), 116(4), 114(10), 91(100); [isoBu]: 223/221 (36/100, M+H), 91(19), 57(18).

2-Butyloxy-5-chloropyrimidine 4b: B.p. 112$114^{\circ} \mathrm{C} / 14 \mathrm{mmHg}$. Anal. $\mathrm{C}_{8} \mathrm{H}_{11} \mathrm{ClN}_{2} \mathrm{O}: \mathrm{C}, \mathrm{H} .{ }^{1} \mathrm{H}$ NMR $\left(\mathrm{CDCl}_{3}\right): \delta 1.03(\mathrm{Me}), 1.2-1.9\left(\mathrm{CH}_{2} \mathrm{CH}_{2}\right)$, $4.33\left(\mathrm{OCH}_{2}\right), 8.38(2 \mathrm{H}-4.6)$. MS $[70 \mathrm{eV} ; \mathrm{m} / z(\% \mathrm{rel}$. int.)]: 188/186 (3/9, M), 133/131 (31/100), 116(9), 114(17), 104(7), 102(21); [isoBu]: $189 / 187$ (30/100, $\mathrm{M}+\mathrm{H}), 131(24), 57(99)$.

2-Allyloxy-5-chloropyrimidine 4c: M.p. $25^{\circ} \mathrm{C}$ (heptane at $-25^{\circ} \mathrm{C}$ ). Anal. $\mathrm{C}_{7} \mathrm{H}_{7} \mathrm{ClN}_{2} \mathrm{O}$ : $\mathrm{C}, \mathrm{H}$. ${ }^{1} \mathrm{H} \mathrm{NMR}\left(\mathrm{CDCl}_{3}\right): \delta 4.85\left(\mathrm{CH}_{2}\right), 5.1-5.5\left(=\mathrm{CH}_{2}\right)$, 5.8-6.4 (CH=), 8.38 (2 H-4.6). MS [70 eV; $m / z(\%$ rel.int.)]: $172 / 170(9 / 31, M), 171 / 169(19 / 55), 116(21)$, 114(54), 41(100); [isoBu]: 173/171 (13/56, M+H), 170(3), 57(100).

2-Propargyloxy-5-chloropyrimidine 4d. Potassium tert-butoxide $(10 \mathrm{mmol})$ was added to propargyl alcohol $(15 \mathrm{ml})$ and the mixture stirred for $10 \mathrm{~min}$ before 2,5 -dichloropyrimidine ${ }^{9}(10 \mathrm{mmol})$ was added. The resultant mixture was stirred at room temperature for $12 \mathrm{~h}$ before the alcohol was removed at reduced pressure. The residue was extracted with ether $(70 \mathrm{ml})$, the solution washed $(2 \times 10 \mathrm{ml})$ and the dried $\left(\mathrm{MgSO}_{4}\right)$ solution evaporated; the residue was the title compound, m.p. $66^{\circ} \mathrm{C}$ (light petroleum m.p. $80-100^{\circ} \mathrm{C}$ ). Anal. $\mathrm{C}_{7} \mathrm{H}_{5} \mathrm{ClN}_{2} \mathrm{O}: \mathrm{C}, \mathrm{H} .{ }^{1} \mathrm{H}$ NMR $\left(\mathrm{CDCl}_{3}\right): \delta 2.51$ 
(三CH), $4.96\left(\mathrm{CH}_{2}\right), 8.45(2 \mathrm{H}-4.6)$. MS [70 eV;

$m / z$ (\% rel.int.)]: 170/168 (24/73, M), 133(53), 116(17), 114(53), 39(100); [isoBu]: 171/169 (38/100, $\mathrm{M}+\mathrm{H})$, 168(13), 57(8).

1. Gacek, M. and Undheim, K. Acta Chem. Scand. B 33 (1979) 515.

2. Gacek, M., Undheim, K., Oftebro, R. and Laland, S. G. FEBS Lett. 98 (1979) 355.

3. Wibe, E., Oftebro, R., Laland, S. G., Pettersen, E. O. and Lindmo, T. Br. J. Cancer 39 (1979) 391.

4. Hopkins, G. C., Jonak, J. P., Tieckelmann, H. and Minnemeyer, H. J. Org. Chem. 31 (1966) 3969.

5. Masse, J. Synthesis (1977) 341 and references therein.

6. Jonczyk, A. and Makosza, M. Rocz. Chem. 49 (1975) 1203.

7. McMinn, D. G. Synthesis (1976) 824.

8. Gacek, M., Thorstad, O., Ongstad, L. and Undheim, K. Chem. Scr. 13 (1978-1979) 99.

9. English, J. P., Clark, J. H., Shepherd, R. G., Marson, H. W., Krapcho, J. and Roblin, R. O. J. Am. Chem. Soc. 68 (1946) 1039.

Received November 25, 1980. 